Chris Wilkinson was the clinical lead for the e-SRH, and Jenny Heathcote was the clinical lead for the clinical components (Course of $5 /$ clinical experience and assessments).

\section{Statements on funding and competing interests \\ Funding None identified.}

Competing interests None identified.

\section{References}

1 Biggs J. What the student does: teaching for enhanced learning. Higher Education Research and Development 1999; 18: $57-75$

2 van der Vleuten CPM. The assessment of professional competence: developments, research and practical implications. Adv Health Sci Educ Theory Pract 1996; 1: 46-67.

3 Postgraduate Medical Education and Training Board (PMETB) Guidance. Developing and Maintaining an Assessment System - A PMETB Guide to Good Practice. January 2007. http://www.pmetb.org.uk/fileadmin/user/QA/Assessment/Asses sment_system_guidance_0107.pdf [Accessed 1 February 2010].
4 Swanson DB, Norman GR, Linn RL. Performance-based assessment: lessons from the health professions. Educational Researcher 1995; 24(5): 5-11, 35.

5 Intercollegiate Surgical Curriculum Programme. Workplace based assessments. https://www.iscp.ac.uk/Assessment/WBA/ Intro.aspx [Accessed 1 February 2010].

6 Royal College of Paediatrics and Child Health. http://www.rcpch.ac.uk/doc.aspx?id_Resource $=3385$ [Accessed 26 February 2010].

7 Norcinii JJ, Burch VC. Workplace-based Assessment as an Educational Tool (AMEE Guide 31). Dundee, UK: Association for Medical Education in Europe, 2008.

8 Norcini J. The power of feedback. Med Educ 2010; 44: 16-17.

9 Department of Health. Public and patient experience and engagement. http://www.dh.gov.uk/en/Managingyour organisation/PatientAndPublicinvolvement/index.htm [Accessed 1 February 2010].

10 Heathcote J. What motivates patients to become involved in postgraduate medical training in a family planning clinic? J Fam Plann Reprod Health Care 2008; 34: 103-106.

\title{
JOURNAL REVIEWS
}

\section{Qualitative research to capture patients' views}

\section{Introduction}

Over the last decade there has been a growing emphasis on the importance of incorporating the views and perceptions of patients or, more generally, service users in health and social care. Qualitative methods often feature as a useful approach to measuring such views. The Journal of Family Planning and Reproductive Health Care is of course not a novice to qualitative approaches, since it has published a series of introductory articles on qualitative methods. ${ }^{1-5}$ This journal review considers three very recent publications in the British Medical Journal, each paper focusing on slightly different aspects of qualitative methods to measure patients' views. ${ }^{6-8}$

\section{Serial qualitative interviews}

The first paper highlights that although face-toface interviews may provide us with a large amount of in-depth information, it can be very much a snapshot of a patient's experiences. ${ }^{6}$ The authors from the University of Edinburgh argue that interviewing a patient at different points during their illness can help to (a) build rapport and develop trust between the interviewer and the interviewee and hence bring out more personal and sensitive issues and (b) capture patients' changing experiences of the disease, their condition and service use. Murray et al. discuss a number of potential issues in serial interviewing, such as when to recruit and when and where to conduct the initial and subsequent interviews, as well as the dropout of interviewees over time and ethical considerations.

The second methods paper by the same research team outlines multi-perspective qualitative interviews, whereby two or more people are interviewed as a set or case study. ${ }^{7}$ This approach attempts to capture complementary as well as contradictory perspectives in people who are in some sort of a relationship with the central interviewee (often the patient). For example, the pivotal interviewee in a study of in vitro fertilisation (IVF) failure would be the women undergoing treatment, but interviewing so-called significant others such as her partner and the IVF treatment midwife may offer greater insight into the woman's perspective. As Kendall and colleagues suggest, multi-perspective interviews can help us understand the relationships and dynamics among patients, their families, carers and service providers, and the different perspectives of each of these interviewees on the situation. Some readers may know the multi-perspective interviewing approach by its subset of couple interviewing.

The third paper appraises qualitative research methods as used alongside randomised controlled trials (RCTs) of complex health care interventions. ${ }^{9}$ Lewin et al. found that only 30 out of 100 trials had a qualitative element, but in twothirds of these trials there was no attempt to integrate the qualitative and quantitative findings, neither in the analysis nor the overall interpretation. The authors conclude that qualitative studies alongside RCTs are still fairly uncommon. The trials that used qualitative methods used these prior to the trial or during the trials, but very few studies used qualitative methods to help explain trial results.

\section{Conclusions}

The first two papers highlighted specific useful ways of applying qualitative methods when eliciting patients' views and perspectives. The authors outline the methods' strengths and, to a lesser extent, their weaknesses for both serial interviewing and multi-perspective interviewing. 6,7 Both papers show what health care researchers can learn from the social and behavioural sciences where qualitative approaches are much more widely used. The third paper offers a more global view on qualitative methods, namely when used alongside RCTs of complex health care interventions. This paper concludes that qualitative methods are making only slow inroads into the more traditional research methods designed to test and generate evidence-based health care interventions. ${ }^{9}$ It is obvious that there is still a long way to go before we make the best possible use of qualitative research methods in health and health care research

\section{Edwin van Teijlingen, MEd, $\mathrm{PhD}$}

Medical Sociologist/Professor of Maternal and Perinatal Health Research, School of Health \& Social Care, Bournemouth

University, Bournemouth, UK.

E-mail:vanteijlingen@bournemouth.ac.uk

References

van Teijlingen ER, Forrest $\mathrm{K}$. The range of qualitative research methods in family planning and reproductive health care, J Fam Plann Reprod Health Care 2004; 30: $171-173$.

2 Forrest Keenan K, van Teijlingen ER. The quality of qualitative research in family planning and reproductive health care, J Fam Plann Reprod Health Care 2004; 30: 257-259.

3 Forrest Keenan K, van Teijlingen E, Pitchforth E. The analysis of qualitative research data in family planning and reproductive health care. J Fam Plann Reprod Health Care 2005; 31: 40-43.

4 Pitchforth E, Porter M, van Teijlingen ER, Forrest Keenan $\mathrm{K}$. Writing up and presenting qualitative research in family planning and reproductive health care. J Fam Plann Reprod Health Care 2005; 31 132-135.

5 van Teijlingen ER, Pitchforth E. Focus group research in family planning and reproductive health care, J Fam Plann Reprod Health Care 2006; 32: 30-32.

6 Murray SA, Kendall M, Carduff E, Worth A, Harris FM, Lloyd $A$, et al. Use of serial qualitative interviews to understand patients' evolving experiences and needs. BMJ 2009; 339: 958-960.

Kendall M, Murray SA, Carduff E, Worth A, Harris F, Lloyd $A$, et al. Use of multiperspective qualitative interviews to understand patients' and carers' beliefs, experiences, and needs. BMJ 2010; 240: 196-199.

Lewin S, Glenton C, Oxman AD. Use of qualitative methods alongside randomised controlled trials of complex healthcare interventions: methodological study. BMJ 2009; 339: b3496.

\section{JOURNAL REVIEW WRITERS}

The Journal regularly reviews articles from related publications and is looking to recruit more volunteers to compile these short reviews. For further information and/or to offer your services (at most once or twice a year) please e-mail your contact details to the Journal Editorial Office together with a note of any special interests and/or expertise to assist us in allocating relevant articles to individual reviewers. For further information on this role please contact the Journal Editorial Office at journal@fsrh.org. 